\title{
Evaluating the predictive ability of a mechanistic model of nitrogen partitioning applied to lactating dairy cows consuming ryegrass-based diets
}

\author{
R.E. VIBART, F.Y. LI, I. VOGELER and R. CICHOTA \\ AgResearch, Grasslands Research Centre, Palmerston North, New Zealand
}

Ronaldo.Vibart@agresearch.co.nz

\begin{abstract}
The ability to understand and predict ruminant nitrogen (N) partitioning has become important as concerns over the environmental impact of pastoral agriculture increase. A mechanistic model of $\mathrm{N}$ partitioning from dairy cows consuming ryegrass was used to quantify the amount of $\mathrm{N}$ secreted in milk, urine, and faeces, and retained in body tissues. Data from lactating dairy cows (13 $\mathrm{N}$ balance experiments) were used to evaluate the model. Predictions for milk, urinary, faecal, and total excreta $\mathrm{N}$ were in agreement with observed values. Empirical models have been successful in predicting $\mathrm{N}$ partitioning from ruminants, but such approaches lack the underlying biological processes and may not apply to all observed values. An improved representation of the underlying mechanisms of $\mathrm{N}$ partitioning and the possibility of identifying areas where knowledge is lacking was achieved by the use of the current mechanistic model.
\end{abstract}

Keywords: Nitrogen, milk N, urinary $\mathrm{N}$, faecal $\mathrm{N}$, empirical, mechanistic.

\section{Introduction}

Nitrogen $(\mathrm{N})$ in animal excreta, urinary $\mathrm{N}$ in particular, represents the largest source of $\mathrm{N}$ losses to the environment from pastoral agriculture. Losses of $\mathrm{N}$ via nitrous oxide $\left(\mathrm{N}_{2} \mathrm{O}\right)$ and nitrate $\left(\mathrm{NO}_{3}^{-}\right)$leaching from pastoral dairying can be considerable; about $85 \%$ of agricultural $\mathrm{N}_{2} \mathrm{O}$ emissions in New Zealand result from $\mathrm{N}$ excreted by grazing ruminants, and annual losses from intensively grazed pastures can be as high as 200 $\mathrm{kg} \mathrm{N}$ per ha via $\mathrm{NO}_{3}^{-}$leaching (Ledgard et al. 2008). Although $\mathrm{N}$ is an important dietary nutrient for high producing dairy cows, and adequate $\mathrm{N}$ in dairy diets is required to maximise production and profitability, $\mathrm{N}$ supply from ryegrass-based pastures is frequently in excess of requirements, whereas carbohydrate supply is often limited (Pacheco \& Waghorn 2007). Consequently, the ability to understand and accurately predict the partitioning of $\mathrm{N}$ in ruminants becomes increasingly important.

Several mechanistic and empirical models have been developed to examine $\mathrm{N}$ partitioning from dairy cows under different nutritional regimes (AFRC 1993; Castillo et al. 2000; Kebreab et al. 2002), but fewer include pasture-based diets (Pacheco et al. 2007). Empirical models have been successful in many situations, but this approach lacks understanding of the underlying biological processes and thus may not be applicable to conditions outside those of its development. Process-based models are more complex but offer the opportunity to reliably study the effects of $\mathrm{N}$ intake on $\mathrm{N}$ partitioning under a wide range of conditions. The objectives of this study were to (i) assess, via a dynamic model of $\mathrm{N}$ metabolism, the efficiency of $\mathrm{N}$ utilisation in dairy cows, with a focus on the amounts of $\mathrm{N}$ secreted ( $\mathrm{N}$ in milk), excreted $(\mathrm{N}$ in urine and faeces) and retained (accretion of $\mathrm{N}$ in body tissues) from ryegrass-based diets, and (ii) identify gaps in the current knowledge of $\mathrm{N}$ partitioning within the dairy cow to focus future investigation.

\section{Methods}

\section{Model overview and assumptions}

The dynamic model of $\mathrm{N}$ partitioning by Kebreab et al. (2002) was used to quantify $\mathrm{N}$ flows and sinks in dairy cows consuming a ryegrass-based pasture. The model is based on a metabolisable energy (ME) and protein system (AFRC 1993), and was originally developed from diets consisting of conserved forages and concentrates. The model includes four state variables representing dietary (Di), amino acid (AA), microbial (Mi) and urea and ammonia (Ur) N (Figure 1).

A number of assumptions were made to calculate the flows between different $\mathrm{N}$ pools. Flows from the dietary $\mathrm{N}$ pool assumed rumen-undegradable protein (RUP) and rumen-degradable protein (RDP) values of 33 and $65 \%$, respectively, and the quantity of preformed AA incorporated into microbial cells was set at $5 \%$ of potentially rumen degradable N (Kebreab et al. 2002). The proportion of digestible RUP N absorbed post-ruminally as AA was set at 0.79 of RUP N (AFRC 1993), and microbial true protein $(75 \%$ of total microbial N) was assumed to be $85 \%$ digestible. 


\section{Data input}

Published information of 48 different treatments from 13 experiments (comprising 710 lactating cows) that included an $\mathrm{N}$ balance component was collated and used to evaluate the model (Table 1). Lactating cows either grazed or were offered freshly-cut grass that comprised $\geq 70 \%$ of the total diet on a DM basis $(88.9 \pm 9.3 \%$ mean $\pm \mathrm{SD}$ ). Selected publications (Astigarraga et al. 2002; Carruthers \& Neil 1997; Carruthers et al. 1997; Mackle et al. 1996; Miller et al. 2000, 2001; Moorby et al. 2006; Mulligan et al. 2004; Pacheco et al. 2003; Peyraud et al. 1997; Rearte unpublished; Tas et al. 2006; Van Vuuren et al. 1993) included data on intake (pasture and supplements) and lactation performance (milk yield and milk protein concentration). The model was run until a steady state was achieved.

\section{Statistics}

The agreement of observed and predicted values was quantified using the concordance correlation coefficient (CCC; Lin 1989), the root of the mean square prediction error (RMSPE) and the relative prediction error (RPE), according to:

$$
\mathrm{CCC}=\frac{2 \sum_{i=1}^{n}(O i-\bar{O})(P i-\bar{P}) / n}{\sum_{i=1}^{n}(O i-\bar{O})^{2} / n+\sum_{i=1}^{n}(P i-\bar{P})^{2} / n+(\bar{P}-\bar{O})^{2}}
$$

$$
\operatorname{RMSPE}=\sqrt{\sum_{i=1}^{n}(O i-P i)^{2} / n}
$$

$$
\mathrm{RPE}=R M S P E / \overline{0} \times 100(\text { in } \%)
$$

where $n$ is the number of paired observations, $O i$ and $P i$ the observed and predicted values, and $\bar{O}$ and $\bar{P}$ are the mean of observed and predicted values.

\section{Results and Discussion}

Although originally designed and evaluated with diets based on conserved forages and concentrates, the model chosen for this purpose (Kebreab et al. 2002) provided for acceptable predictions of $\mathrm{N}$ partitioning, particularly

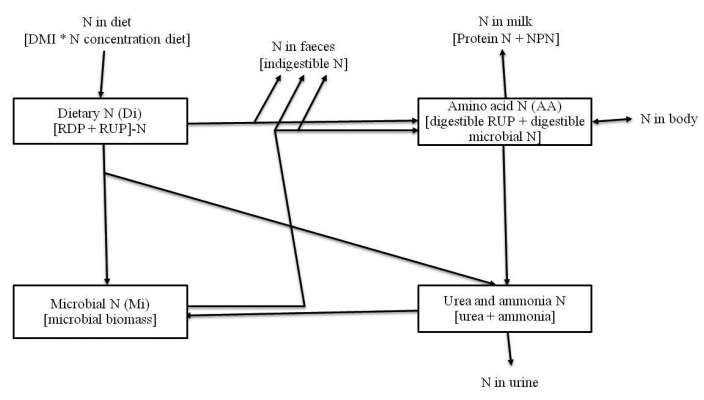

$\mathrm{RDP}=$ rumen degradable protein; RUP = rumen undegradable protein .

Figure 1 Schematic representation of $\mathrm{N}$ pools (boxes) and fluxes of the dynamic model of $\mathrm{N}$ metabolism (Kebreab et al. 2002). Inputs and outputs to and from the pools are represented by arrows.

$\mathrm{N}$ in milk, $\mathrm{N}$ in urine and $\mathrm{N}$ in total excreta (Table 2). Predicted milk $\mathrm{N}$ output was close to observed values. To a lesser degree, predicted urinary and total excreta $\mathrm{N}$ were also close to observed values, with acceptable RPE values and minor deviation of the regression slope from unity. Although having an acceptable RPE value, predicted faecal $\mathrm{N}$ showed a substantial deviation of the regression slope from unity (Figure 2).

The pattern for milk $\mathrm{N}$ could be attributable to changes in the amount and origin of AA supplied for milk synthesis. With intakes of up to $c a .450 \mathrm{~g} \mathrm{~N} /$ day, the supply of AA for milk synthesis originated from microbial and dietary sources. Beyond this point, microbial protein synthesis (MPS) could have reached a plateau, and the supply of AA for milk synthesis relied heavily on RUP sources, hence the less steep rate of increase in milk N. In grass-based diets, this process is often exacerbated by the absence of readily available sources of energy in the form of water soluble carbohydrates (WSC) to allow for continued capture of $\mathrm{N}$ by microorganisms in combination with extensive and rapid crude protein $(\mathrm{CP})$ degradation of ryegrass-based diets in the rumen (Chaves et al. 2006). In agreement with these findings, Pacheco et al. (2007) described a similar relationship between the efficiency

Table 1 Summary (mean, standard deviation, and range) of the data collated from 13 experiments used to evaluate the mechanistic model (Kebreab et al. 2002) DMI = dry matter intake.

\begin{tabular}{lccc}
\hline Variable & Mean & SD & Range \\
\hline DMI, kg/day & 16.4 & 2.8 & $10.3-21.5$ \\
Milk yield, kg/day & 21.4 & 5.5 & $10.3-32.7$ \\
Milk protein, g/kg & 33.0 & 2.2 & $28.2-38.2$ \\
N intake, g/day & 455.4 & 100.4 & $263.0-632.0$ \\
N output, g/day & & & $56.0-152.0$ \\
N in milk & 109.3 & 23.9 & $64.0-342.0$ \\
N in urine & 215.9 & 82.4 & $82.0-193.0$ \\
N in faeces & 119.8 & 21.7 &
\end{tabular}


a)

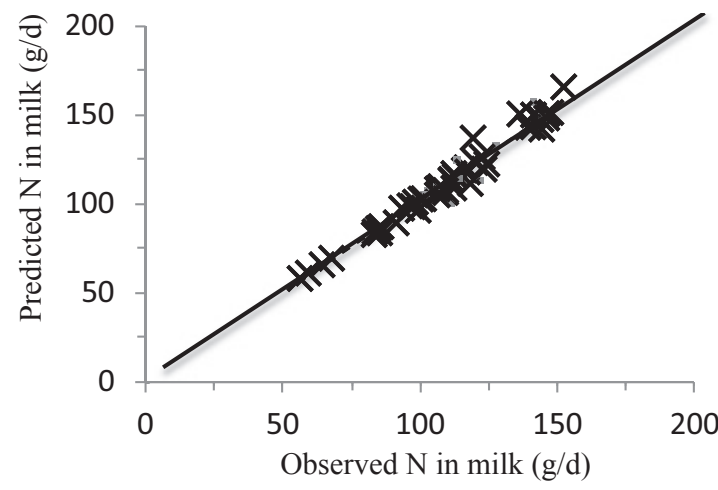

b)

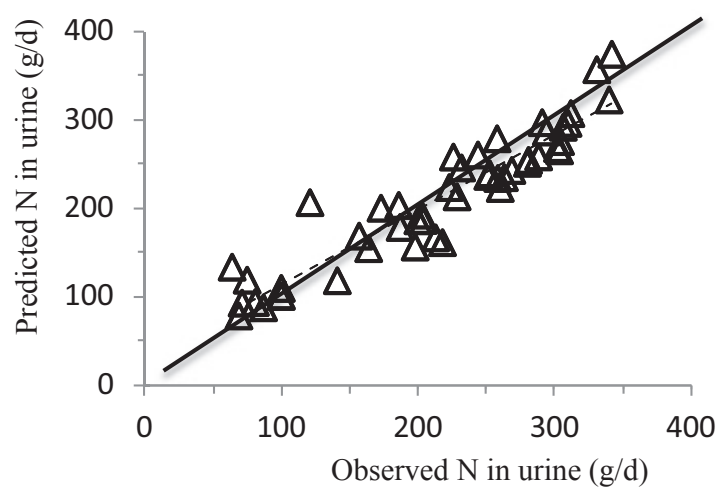

c)

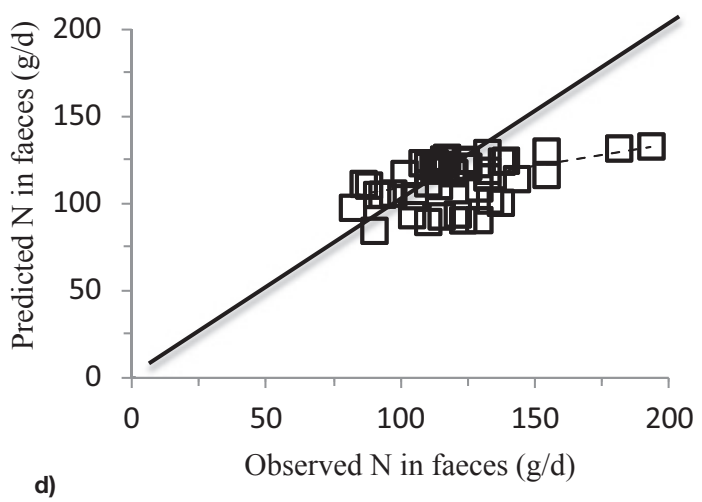

d)

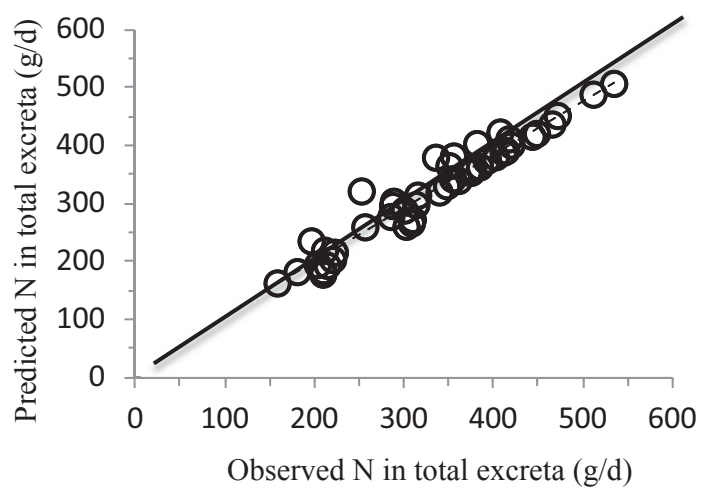

Figure 2 Relationships between observed and predicted values of $\mathrm{N}$ in a) milk ( $\times$ ), b) urine $(\Delta), \mathrm{c})$ faeces ( $\square$ ) and d) total excreta ( $(\circ)$. Solid lines represent agreement relative to a $45^{\circ}$ line through the origin whereas dashed lines represent the best linear fit between variables.

of $\mathrm{N}$ utilisation and the ratio of $\mathrm{CP}$ to WSC for perennial ryegrasses.

Urine and faecal excretion accounted for almost all remaining $\mathrm{N}$ input. As energy became limiting for MPS, the relative contribution of microbial faecal $\mathrm{N}$ to total faecal $\mathrm{N}$ diminished. Conversely, as energy supply is often rate-limiting for MPS from grass-based diets, increases in $\mathrm{N}$ without adequate supplies of energy resulted in surplus $\mathrm{N}$, which was largely excreted via urine. In agreement with previous findings (Castillo et al. 2000; Kebreab et al. 2002), the relationship between urine $\mathrm{N}$ and intake $\mathrm{N}$ showed an inflection point at $c a .450 \mathrm{~g} \mathrm{~N} /$ day, above which the predicted values of urinary $\mathrm{N}$ output were under-predicted. Unlike Castillo et al. (2000), where excretion of $\mathrm{N}$ in urine above 400 $\mathrm{g} \mathrm{N}$ intake/day increased exponentially, excretion of $\mathrm{N}$ in urine followed a quadratic or bi-linear relationship (results not shown).

It is interesting to note that, based on the same measures of predictive ability, the $\mathrm{N}$ partitioning approach used by OVERSEER ${ }^{\circledR}\left[\mathrm{N}_{\text {urine }}=\left(11.0_{( \pm 1.1)}\right.\right.$ $\times \% \mathrm{~N}$ in diet $\left.)+31.8_{( \pm 3.5)}\right]$ produced estimates of $\mathrm{N}$

Table 2 Measures of fitness (RMSPE, RPE, CCC) ${ }^{1}$ of predicted vs. observed values of $\mathrm{N}$ partitioning in lactating dairy cows fed ryegrass-based diets.

\begin{tabular}{lccc}
\hline Variables & RMSPE & RPE & CCC \\
\hline N in milk & 4.2 & 3.8 & 0.98 \\
$N$ in urine & 25.9 & 12.2 & 0.93 \\
$N$ in faeces & 11.5 & 10.1 & 0.36 \\
N in total excreta & 21.6 & 6.6 & 0.96 \\
\hline
\end{tabular}

${ }^{1} \mathrm{RMSPE}$ is the root of the mean square prediction error ( $\mathrm{g} /$ day); RPE is the relative prediction error (\%); and CCC is the concordance correlation coefficient (scale 0 to 1 ). 
in urine in line with the experimental data used here $(\mathrm{RMSPE}=19.9 \mathrm{~g} / \mathrm{day}, \mathrm{RPE}=9.3 \%, \mathrm{CCC}=0.95)$. This shows that simple empirical models can produce reasonable estimates of $\mathrm{N}$ excretion. However, the lack of a dynamic representation of dietary and metabolism changes makes such models less sensitive to variations in feeding strategy. Accounting for these variations is important, for instance, when analysing "what if" scenarios altering dietary strategies to address environmental issues.

Two recognised gaps in current knowledge relative to $\mathrm{N}$ partitioning prediction are noted. The first area relates to preformed AA uptake by microorganisms that contributes to the microbial $\mathrm{N}$ pool, particularly from pasture-based diets. Uptake of preformed peptides spares the cost of de novo microbial AA synthesis. Plant CP undergoes intensive degradation in the rumen, vastly to ammonia; nitrogenous components kinetics from ryegrasses harvested at different stages of maturity showed that the proportion of CP as RDP averaged 0.83 , and maturation did not affect the ratio of RDP to RUP (Chaves et al. 2006). The process of intensive plant proteolysis in the rumen is suggested to be exacerbated by increased feeding frequency in grazing situations (Chen et al. 1987). An adequate and dynamic range of RDP/RUP values will be expected if the underlying mechanisms of reduced $\mathrm{N}$ loss management (i.e. timing of herbage allocation, grazing interval, the use of high sugar grasses, the use and timing of energy-dense, low protein supplements) are to be understood and implemented in grazing systems.

The second area relates to body $\mathrm{N}$ accretion/ degradation during the entire lactation. Studies that have quantified $\mathrm{N}$ partition during different stages of lactation are scarce, and refer mostly to confinementtype diets (Andrew et al. 1994; Chilliard et al. 1991) or predict body lipid changes (Friggens et al. 2004). Although fluctuations may be minor relative to dietary $\mathrm{N}$, body deposition of $\mathrm{N}$ may become important during the first weeks of lactation, mid to late lactation, and during the dry period. Accretion of $\mathrm{N}$ by body tissues of lactating dairy cows offered ryegrass-based diets accounted for up to 89 and $54 \mathrm{~g} \mathrm{~N} /$ day during mid lactation (>140 DIM; Miller et al. 2000).

Nitrogen intake continues to be the main driver of $\mathrm{N}$ excretion, but the level of $\mathrm{N}$ intake (modulated by spatial and temporal fluctuations) relative to animal requirements (modulated by milk production and body protein accretion/degradation) modifies this response. Model predictions of milk, urinary, faecal and total excreta $\mathrm{N}$ were in agreement with observed values. In order to improve our current understanding on how $\mathrm{N}$ is partitioned within the dairy cow, more research needs to be conducted in the areas of preformed amino acid uptake by microorganisms in the rumen, particularly from pasture-based diets; and how body $\mathrm{N}$ accretion/ degradation is affected by stage of lactation.

\section{ACKNOWLEDGEMENTS}

The authors thank Val Snow, Mark Shepherd, Alec Mackay, Grant Douglas (AgResearch) and Pablo Gregorini (DairyNZ) for their valuable input. The project was funded by DairyNZ as part of project AGR119 (The fate of autumn applied $\mathrm{N}$ fertiliser relative to other seasons).

\section{REFERENCES}

AFRC. 1993. Energy and protein requirements of ruminants. Agricultural and Food Research Council. CAB International, Wallingford, UK.

Andrew, S.M.; Waldo, D.R.; Erdman, R.A. 1994. Direct analysis of body composition of dairy cows at three physiological stages. Journal of Dairy Science 77: 3022-3033.

Astigarraga, L.; Peyraud, J.L.; Delaby, L. 2002. Effect of nitrogen fertiliser rate and protein supplementation on the herbage intake and the nitrogen balance of grazing dairy cows. Animal Research 51: 279-293.

Carruthers, V.R.; Neil, P.G. 1997. Milk production and ruminal metabolites from cows offered two pasture diets supplemented with non-structural carbohydrate. New Zealand Journal of Agricultural Research 40: 513-521.

Carruthers, V.R.; Neil, P.G.; Dalley, D.E. 1997. Effect of altering the non-structural: structural carbohydrate ratio in a pasture diet on milk production and ruminal metabolites in cows in early and late lactation. Animal Science 64: 393-402.

Castillo, A.R.; Kebreab, E.; Beever, D.E.; France, J. 2000. A review of efficiency and nitrogen utilization in lactating dairy cows and its relationship with environmental pollution. Journal of Animal and Feed Sciences 9: 1-32.

Chaves, A.V.; Waghorn, G.C.; Brookes, I.M.; Woodfield, D.R. 2006. Effect of maturation and initial harvest dates on the nutritive characteristics of ryegrass (Lolium perenne L.). Animal Feed Science and Technology 127: 293-318.

Chen, G.; Sniffen, C.J.; Russell, J.B. 1987. Concentration and estimated flow of peptides from the rumen of dairy cattle: Effects of protein quantity, protein solubility, and feeding frequency. Journal of Dairy Science 70: 983-992. 
Chilliard, Y.; Cisse, M.; Lefaivre, R.; Rwenond, B. 1991. Body composition of dairy cows according to lactation stage, somatotropin treatment, and concentrate supplementation. Journal of Dairy Science 74: 3103-3116.

Friggens, N.C.; Ingvartsen, K.L.; Emmans, G.C. 2004. Prediction of body lipid change in pregnancy and lactation. Journal of Dairy Science 87: 988-1000.

Kebreab, E.; France, J.; Mills, J.A.N.; Allison, R.; Dijkstra, J. 2002. A dynamic model of N metabolism in the lactating dairy cow and an assessment of impact of $\mathrm{N}$ excretion on the environment. Journal of Animal Science 80: 248-259.

Ledgard, S.F.; Menneer, J.C.; Dexter, M.M.; Kear, M.J.; Lindsey, S.; Peters, J.S.; Pacheco, D. 2008. A novel concept to reduce nitrogen losses from grazed pastures by administering soil nitrogen process inhibitors to ruminant animals: a study with sheep. Agriculture, Ecosystems and Environment 125: 148-158.

Lin, L.I-K. 1989. A concordance correlation coefficient to evaluate reproducibility. Biometrics 45: 255-268.

Mackle, T.R.; Parr, C.R.; Bryant, A.M. 1996. Nitrogen fertiliser effects on milk yield and composition, pasture intake, nitrogen and energy partitioning, and rumen fermentation parameters of dairy cows in early lactation. New Zealand Journal of Agricultural Research 39: 341-356.

Miller, L.A.; Moorby, J.M.; Davies, D.R.; Humphreys, M.O.; Scollan, N.D.; MacRae, J.C.; Theodorou, M.K. 2001. Increased concentration of water-soluble carbohydrate in perennial ryegrass (Lolium perenne L.): milk production from late-lactation dairy cows. Grass and Forage Science 56: 383-394.

Miller, L.A.; Theodorou, M.K.; MacRae, J.C.; Evans, R.T.; Humphreys, M.O.; Scollan, N.D.; Moorby, J.M. 2000. Efficiency of nitrogen use by dairy cows offered perennial ryegrass with high water soluble carbohydrate concentrations. pp. 37-38. In: Proceedings of the 6th Research Conference of the British Grassland Society.
Moorby, J.M.; Evans, R.T.; Scollan, N.D.; MacRae, J.C.; Theodorou, M.K. 2006. Increased concentration of water-soluble carbohydrate in perennial ryegrass (Lolium perenne L.). Evaluation in dairy cows in early lactation. Grass and Forage Science 61: 52-59.

Mulligan, F.J.; Dillon, P.; Callan, J.J.; Rath, M.; O'Mara, F.P. 2004. Supplementary concentrate type affects nitrogen excretion of grazing dairy cows. Journal of Dairy Science 87: 3451-3460.

Pacheco, D.; Burke, J.L.; Cosgrove, G.P. 2007. An empirical model to estimate efficiency of nitrogen utilisation in cows grazing fresh forages. pp. 409416 In: Meeting the Challenges for Pasture-Based Dairying. Proceedings of the Australasian Dairy Science Symposium. Melbourne, Australia.

Pacheco, D.; Tavendale, M.H.; Reynolds, G.W.; Barry, T.N.; Lee, J.; McNabb, W.C. 2003. Wholebody fluxes and partitioning of amino acids to the mammary gland of cows fed fresh pasture at two levels of intake during early lactation. British Journal of Nutrition 90: 271-281.

Pacheco, D.; Waghorn, G.C. 2008. Dietary nitrogen definitions, digestion, excretion and consequences of excess for grazing ruminants. Proceedings of the New Zealand Grassland Association 70: 107-116.

Peyraud, J.; Astigarraga, L.L.; Faverdin, P. 1997. Digestion of fresh perennial ryegrass fertilized at two levels of nitrogen by lactating dairy cows. Animal Feed Science and Technology 64: 155-171.

Tas, B.M.; Taweel, H.Z.; Smit, H.J.; Elgersma, A.; Dijkstra, J.; Tamminga, S. 2006. Effects of perennial ryegrass cultivars on milk yield and nitrogen utilization in grazing dairy cows. Journal of Dairy Science 89: 3494-3500.

Van Vuuren, A.M.; Van Der Koelen, C.J.; Valk, H.; De Visser, H. 1993. Effects of partial replacement of ryegrass by low protein feeds on rumen fermentation and nitrogen loss by dairy cows. Journal of Dairy Science 76: 2982-2993. 
